\title{
Translating the MaladiesIraq through the Eyes of its Translators in George Packer's Betrayed
}

\author{
Prof. Hana Khlaif Ghena \\ College of Arts/Department of Translation \\ Al-Mustansiriya University \\ h.horizons2013@gmail.com
}

\begin{abstract}
Drawing on Mona Baker's seminal work about the translators in the war zone and Thomas $O$. Beebee's concept of transtraitor, this paper argues that more than a mere linguistic act, working as interpreters and translators in post-2003 Iraq is a multi-dimensional act that engages the interpreters/translators socially, economically and culturally. In George Packer's Betrayed, the three translators, Laith, Adnan, and Intisar present a bleak image of post-2003 Iraqi society that is torn apart by violence, fear and sectarian divisions. In their fears, restlessness, and feelings of disappointment, they become microcosms that reflect the larger macrocosm; namely, the Iraqi society. The paper is divided into two sections and a conclusion. Section one gives an account of the complex and dangerous situation in Iraq after the entrance of the American forces in 2003. Section two presents the changes which the Iraqi society has been witnessing since 2003 through the eyes of the translators. The conclusion argues that Iraqis in general have been leading a very precarious and hazardous life. However, because of the negative attitudes toward the interpreters/translators as they are viewed as traitors and collaborators with the enemy, they were leading a more perilous and troublesome life.
\end{abstract}

Keywords : Iraq, interpreters/translators, Baker, Beebee, and war.

\section{INTRODUCTION}

After the entrance of the American military forces in Iraq in 2003, hundreds of Iraqis who master English language engaged, for various reasons, in working with these forces as interpreters and translators. However, they quickly become targets for armed groups of different affiliations and affinities. As working as translators with these forces become more and more death-defying and terrifying, translators were forced to resort to different means to protect themselves and their families from the retaliating and vengeful attacks of the armed groups. These means ranged from concealing the nature of their works, "covering their faces with ski masks and sunglasses as they venture outside the military bases and adopt American pseudonyms such as 'Eric' or 'Sally' so as to protect themselves from being singled out for insurgent attacks"(Rafael, 2009,p.15), changing their dialect while translating to delude the [Iraqi] listeners into thinking that they are from other Arab countries, to seeking asylum abroad especially after the withdrawal of these forces in 2011 after the signing of USIraq Status of Forces Agreement between the American and Iraqi governments. These measures were not successful all the time as hundreds of Iraqi translators lost their lives in accidents of snipeshooting, assassination, or kidnapping. In fact, not only the translators were leading unsafe lives, but also their families especially if the nature of their work is made known in their neighborhoods (Juvinall, 2013, p.206). Even those who succeeded in getting special Immigrants Visas to the United States were not in a privileged position as "Many former interpreters currently face the decision to either remain in the U.S. with little opportunity to support themselves and their families or to return to Iraq where they risk being murdered for their assistance to U.S. forces" (King qtd in Juvinall, 2013, p.206). More important as some translators explain, the Iraqi translators were suspected and distrusted not only by their fellow citizens who believe that they deserve death more than the Americans, but also by the Americans themselves. The latter feared that the translators, whether Iraqis or American of Iraqi origin, might be spies informing the armed groups of the movements of the American forces. As one U.S. soldier puts it, "These guys [i.e., interpreters] have guts to do what they do. And we'd be nowhere without them. We'd be lost. But you always have this fear that they might be leaking op-sec [operational security] stuff. You want to trust them, but you're still reserved."(Levinson qtd in Rafael,2009, p.16) As a result, the translators were constantly subject to precautionary measures and 
tight surveillance. They were not allowed to make statement or interviews with the journalists. They also were not allowed to talk about the nature of their work without an official book of permission. Any translator who violated these rules would be subject to intensive investigation or given the sack (Omar,2008). Amos (qtd in Rafael, p.16) gives a bleaker picture of life of the interpreters in the war zone as they are "the only ones searched within the base (especially after every meal) and forbidden to carry cell phones and cameras, send e-mail, play video games, and...even swim in the pool." To this, Washburn (qtd in Ibid) adds the interpreters are often subjected to "incessant racial insults "raghead," "jihad," and "camel jockey," among others — and at the same time are forced to exit the base with neither weapons nor armor to protect themselves." As a result, the interpreters become doubly alienated. They are "aliens in their new surroundings, [and]... alienated from their own countrymen"(Ibid). They more often than not "became terrorized from 'within' and deemed as terrorists from "without" (Blumenauer qtd in Chou, 2009, p.3).

In her seminal study, "Interpreters and Translators in the War Zone: Narrated and Narrators," Baker (2010) gives a succinct account of the dangers encountered by translators in the war zones. In this account, she focuses on two points that share a common ground, namely; the act of narration. In the first of these points, Baker is concerned with elucidating "how translators and interpreters are narrated by other participants in the war zone, including military personnel, war correspondents, mainstream media, alternative media and local populations," while in the second she is concerned with explaining how the interpreters/translators themselves "participate in elaborating the range of public narratives of the conflict that become available to us, and, in so doing, influence the course of the war in ways that are subtle, often invisible, but nevertheless extremely significant"(Ibid, p.197).

In times of wars and conflicts, two important assumptions are usually raised; that is of difference and homogeneity. As soon as a war is declared, the involved parties begin to adopt two entirely different stances in dealing with each other. Typically, the 'US/THEM' position or storyline dominates the war scene. Accordingly the enemy after 2003; i.e., the Americans are "evil, threatening, dangerously out of control and intransigent. [They] represent the opposite of everything we stand for: we are civilized, fair, level-headed, peace-loving, reasonable and open to compromise," while we, the Iraqis, "value life and freedom, they are out to kill and enslave us"(Baker, 2010, p.198). In view of that, the position of the translator, as one of us or them "becomes extremely important," and often involves "lifethreatening consequences"(Ibid). This assumption becomes deeply rooted and consolidated by the equally important assumption of homogeneity which allows little or no room for "negotiate[ing] a more tolerant, more accommodating relationship even with the odd member of the 'enemy' camp, and no 'in-between' space of the type that romantic theories of translation tend to assign them to"(Ibid).

Because of the dominance of these two assumptions, Beebee coins the term 'transtraitors', a "term that aptly describes translators throughout history as those perceived as suspiciously strange, who possess some kind of special knowledge, who fraternize with the enemy, who cannot be trusted"(qtd in Inghilleri and Harding, 2010,p.171). Beebee also discusses the position of the translator in situations of violent conflict in relation to the term homer sacer as applied by Giorgio Agamben - a transgressor who is neither punished nor protected and may be killed with impunity (Ibid). This view of the translator as a traitor, or as someone who is "Sleeping with the enemy,"(qtd in Zagolin, 2015, p.7) and who should be killed is made crystal clear in an statement issued by Zaibullah Mujahid, the official spokesman of Taliban movement, "Our policy is that, whoever protects and supports foreigners as translators, they are national traitors for us and the people of Afghanistan and like the foreign soldiers and foreign occupiers they will be put to death" (qtd in ibid, p.11). This may explain why translators in Iraq, regardless of their ethnic or religious affiliation, i.e., Shia or Sunni, become "targets of intimidation, ostracism, torture, and murder...in a country beset with suspicion, antipathy and violence"(Chou,2009,p.3).

No doubt the roles played by the interpreters and translators in the zones of violent conflicts are, more often than not, "complex, dynamic and multi-faceted" regardless of the nature of their participation; whether it is a direct participation in war zones or indirect in legal and humanitarian contexts (Inghilleri and Harding,2010, p.165). Inghilleri and Harding go on to point out that

Because of the physical, cultural or linguistic proximity of interpreters and translators to one side or the other in a given conflict, there is a powerful tendency by the different parties, including the public, to position interpreters and translators as loyal to one side and opposed to another. (Ibid) 
In fact, this position is highly affected by the ways the interpreters/translators are "narrated by others" (Baker, 2010,p.204). These different and often contradictory ways of looking at the them often result in a "chasm that gradually opens up between their own sense of identity, their own personal narrative, and the identity and narrative imposed on them by other parties who both need and fear them" (Ibid). Consequently, the identity of translators and interpreters working in the conflict zones becomes "unsettled and unsettling inasmuch as their presence generates both relief and suspicion among soldiers" (Rafael, 2009, p.15). Thus, under these circumstances, the positioning of translators/interpreters between two completely different poles as either victim or villain, a friend or foe, trustworthy allies or security threats, is quite natural(for more information, see Baker, 2010, pp.204-217).

Apart from these ambivalent attitudes toward the interpreters/translators, the importance of the roles they play in the zones of conflict is undeniable. Among these roles are stringer, fixers and proxy journalists (See Palmer in Salama-Carr, 2007, p.16). In these roles, they perform a range of "tasks beyond the purely linguistic transfer of information, such as arranging meetings or acting as drivers"(Palmer, in Zagolin, 2015, p.10). they also engage in

interpreting in interviews and translating local media; arranging interviews, including... [de]selecting the interviewee; background briefings about the identities of potential interviewees, situations, social groups, etc.; some reporting, especially summaries of events to which the [Western] journalist cannot have access ... security assessments, due to the level of danger caused by the degradation of the security situation; access to networks of local contacts; protection for journalists via the fixers' links with local networks of influence, and - if necessary - negotiation with kidnappers.(Palmer in SalamaCarr, 2007, p.19)

In addition to these roles, interpreters/translators become direct or indirect chroniclers and narrators of war. Elaborating on the nature of this issue is the main topic in Peter's report "An Iraqi Interpreter as Chronicler of the War"(2008) in which he talks about the Iraqi interpreters as the "unofficial historians" of post-2003 war in Iraq. Peter curtly sheds light on the nature of this role. He says

While many US soldiers have served multiple tours in Iraq, a core group of Iraqi interpreters have worked with the US for almost the entire war. But unlike the soldiers that they work for, they don't leave. Rooted in the conflict, they've become the unofficial chroniclers of the war, watching its ups and downs, and passing along to military newcomers the story of the battle for Iraq.

In this way, the Iraqi interpreters "not only help [the Americans] overcome language barriers but also...point [...] out the changes" that were taking place in the Iraqi battle-weary scene. Brad, the nicknamed Iraqi interpreter and the central character in Peter's report illuminates his role as a chronicler of war. He states "When the Americans came here, they didn't know anything about this country, the culture, the streets, and how to deal with Iraqis, so I believed we should stand and help them, and I did"(qtd in Peter, 2008). Brad further comments on the importance of the translators in making a change in the war situation. He points out:

I think some of the impressions the Americans had when they first came have been changed. This is why some of the mistakes that happened in the past are now getting fixed, because they know more about the Iraqis ... and they can handle the situation better than when they first came here. (Ibid)

Because of their continuous presence as a linguistic mediators, the local interpreters, Baker (2010, p.213) believes "provide the continuity of narration that ultimately makes it possible for others to write a history, a chronicle of the events and relationships that define the war." In other words, they help "piece the narrative together for the next group of military personnel, journalists, charity workers or peace keepers"(Ibid). Certainly, translators exercise considerable influence on the way the war is narrated. In spite of being doubted, they generally have "considerable freedom in construing the nature of their task and interpreting the immediate event for their interlocutors"(Ibid, p.214) They can also report the " "gist' of what others say, as they understand or wish to present it, rather than being obliged to translate their utterances closely"(Ibid). Consequently, the interpreters usually have "considerable latitude as narrators and can influence the unfolding narrative in ways that are hardly ever acknowledged by their interlocutors" (Ibid). 
Other roles played by the translators are the [temporary] combatant and the cultural consultant. Since the translators accompany the soldiers all the time, whether they are in the military bases or out on missions, it is natural that they are sometimes involved and participate in a variety of activities that range from

intelligence and counter intelligence activities to combat areas, including remote outposts and behind-the-enemy-line zones, where their services may have varied from regular liaison with allied troops to logistical dealings with local civil populations and from interrogation of war prisoners to surrender of enemy units. (Baigorri-Jalon, 2010, p.180)

These activities mean that although the translators are non-military staff, they are subject to the same dangers and risks just like the military. The following episode narrated by Lieutenant Colonel R. Alan King when he was in Iraq makes this evident: "“Damn it Salih" I yelled back, "shoot, just shoot" and both Salih and I continued to fire". These were the instructions he gave to the interpreter that was accompanying his patrol. Consequently, "The action 'other-than-interpreting' can form an integral part of the interpreter's activity. Typically positioned as a non-combatant, the interpreter may have no choice but to engage in some form of combat in order to survive" (Tipon qtd in Zagolin, 2015, p.10).

Since the act of translation takes place in a socio-cultural context, the translator's knowledge and awareness of the cultural and social practices and beliefs of the parties he is linguistically interacting with is of prime importance (Hatim and Mason qtd in Akbari, 2013, p.13). This awareness gains in more importance in the war zones, as one of the tasks performed by translators is to provide the "public face of the occupation"(Levinson, Rafael, 2009, p.16). Informing the American forces of some culture-specific information about, for example, the position of women, the dealing with the Mosques and other religious sites, naming, concepts of time and honor, proves to be very important in avoiding misunderstanding.

Besides the above-mentioned roles, the translators often play another vital role, which is of portraying the maladies, aspirations, expectations as well as the disappointments and frustrations of their societies. In giving vent to their aborted dreams of change, fears and anxieties, the three translators/main characters in George Packer's Betrayed provide the spectators/readers with a very heart-rending picture of a society that was writhing of pain under the repressive rule of Saddam Hussein (1937-2005)before 2003 and torn apart by violence and divisions after it. They become a microcosm that reflects the macrocosm, i.e., the Iraqi society.

\section{LIFE IN IRAQ IN PACKER'S BETRAYed: THE THREAT IS ALWAYS THERE}

In his introduction to Betrayed(2008) which he dedicates for "the Iraqis who gave me their wordsAmeer, Ayad, Ban, Ehab, Firas, Hossam, Intisar, Laith, Mwaffaq, Omer, Tona and Yaghdan", Packer (1960-) talks about the genesis of his play and gives a moving picture of the dangerous situation the Iraqi interpreters and translators were confronting. In his sixth visit to Iraq, in 2007, Packer plans to write an article for The New Yorker about "that tiny minority of mostly young men and women who had embraced the American project in Iraq so enthusiastically that they were willing to risk their lives for it"(vii). However, meeting them, Packer admits, was not an easy task. Because of the continuous deterioration in the security situation, the translators were either too terrified to meet him personally or they had already left Iraq to safer places like Amman, Damascus or even Malmo in Sweden. Tracking some of these translators whether abroad or inside Iraq, in the safe Kurdistan, in the tightlyguarded Green Zone in Baghdad or talking via cellphone, Packer notices that there is a "single overwhelming story" in their narration of their work and war experiences. This story revolves around their homeland that is ravaged by sectarian divisions and violence.

After 2003, normal existence in Iraq was impossible for people in general and the translators in particular. In "As Iraqis See It," Messing succinctly described the situation of Iraqis 'expressing anger and gloom, exasperation and despair.' He says:

The overwhelming sense is that of a society undergoing a catastrophic breakdown from the never-ending waves of violence, criminality, and brutality inflicted on it by insurgents, militias, jihadis, terrorists, soldiers, policemen, bodyguards, mercenaries, armed gangs, warlords, kidnappers and everyday thugs. 'Inside Iraq' [the name of the Iraqi blog he is describing] suggests how 
the relentless and cumulative effects of these various vicious crimes have degraded virtually every aspect of the nation's social, economic, professional, and personal life. (qtd in Adelman, 2008, p.184)

Because of the negative attitudes towards the translators as 'traitors,' 'double agents,' 'back stabber,' and 'collaborators with the enemy,' the Iraqi translators were forced to lead "double... precarious, furtive lives". To survive, they resort to various psychologically stressful means such as "using assumed names, limiting their contacts to a handful of trusted people, creating elaborate lies about their history and employment, afraid every time the phone rang or someone knocked on the door"(Packer, 2008,vii).

For Packer, the essential experience of the Iraqi war is vividly embedded in the translators' lives and stories that follow a strict trajectory from "suffering to hope...through a slow, reluctant, increasingly brutal process of disillusionment to a sense of abandonment and betrayal"(Ibid,viii). Unfortunately, those translators who believed they would gain much from the overthrow of the tyrannical Saddamist regime, "lost the most when they became pariah and outcasts in their own society"(Ibid,pp.viii-ix)

This draws our attention to the significance of the title which is based on Packer's The New Yorker article "Betrayed-'The Iraqis who trusted America the Most"(2007) in which he describes his meeting with Othman and Laith in the nearly vacant Palestine hotel, "the only place where they were willing to be seen with the American." The stories narrated by Othman, a twenty nine years old Sunni doctor, and Laith, a younger Fili Shiite engineer, give very horrifying and dreary accounts of life in Iraq. Othman, for example, "was trapped for two nights at his sister's house, which was in an ethnically mixed neighborhood: gun battles had broken out between ... militiamen"(Ibid). He "was able to leave the house only because his sister's husband - a Shiite, who was known to the local Shia militiasescorted him out"(Ibid). As a matter of fact, both of them feel, just like Adnan and Laith who were modeled after them, that they were "standing in line for a ticket, waiting to die"(Packer, 2008,p. 10).

Despite Laith and Othman's strong friendship, which was based on a shared desire for the arrival of the Americans to change their lives, their secular orientations, and scorn of extremism of all sorts, "the ethnic conflict had led them increasingly to quarrel, to the point that one of them...would refuse to speak to the other"(Ibid). Because of its importance to the play, the following dialogue is worth quoting in full with some modifications:

Laith began to describe these strains.

Laith: It started when the Americans came with Shia leaders and wanted to give the Shia leadership-

Othman: "And kick out the Sunnis, You admit this? You were not admitting it before.

Laith: The Americans don't want to kick out the Sunnis. They want to give Shia the power because most Iraqis are Shia.

Othman: And you believe the Sunnis did not want to participate, right? The Americans didn't give them the chance to participate. You know [to Packer] I'm not just saying this because I'm a Sunni-

Laith (rolled his eyes): Whatever.

Packer:But I think the Shia made the Sunnis feel that they're against them.

Laith (heatedly):This is not the point, who started it, everybody is getting killed, the Shia and the Sunnis. But if we think who started it, I think the Sunnis started it!

Othman (with calm knowingness): I think the Shia,[To Packer] When I feel that I'm pushing too much and he starts to become so angry, I pull the brake. (Ibid)

The importance of this dialogue lies in the fact that Betrayed is exclusively built on the stories the translators inform Packer of in these interviews. These stories vividly articulate the drastic changes that befell Iraq after 2003. The opening of the play, which takes place in "A dark, spare hotel room in Baghdad, furnished in the soulless style of the Baathist era," contains many references to these changes such as the lack of security, the shortage of food, bombs and weapons, fighting between the American forces and Al-Qaeda in Amiriya, beheading of a teacher in Adnan's neighborhood, and the emergence of sectarian divided areas in Baghdad. What is more important is the emergence of 'alaasa' 
who are "informers who sit all day in the street and watch for the people they consider the enemy. It means "the ones who chew"(p.8). Revealing your real sectarian identity, i.e., Sunni or Shia', in the wrong place to the wrong party means death. Therefore, both Laith and Adnan were forced to carry "fake ID[s] for different parts of Baghdad"(p.9).

Adnan makes comparison between the pre and post-2003 Iraq. In spite of the obvious differences between the two periods, Adnan and the other young men of his generation were far from leading a comfortable life. Each period has its own challenges and aborted dreams. Adnan talks about his life under Saddam's rule in which 'everything was banned' and everyone was busy-minded with the prolonged war with Iran that lasted for eight years. Therefore, he feels that he is a non-belonger; he is one of those who always thought that they do not belong to their societies. This sense of estrangement and disaffection becomes worse as he fails to get a job that answers to his university education and instead engages in "selling cigarettes, selling spare parts, selling books on Mutanabi Street"(p.11) to eke his living.

Besides working as translators, fixers, proxy journalists, and chroniclers of war, Adnan and Laith play other important roles in Betrayed. First and foremost, they are characters whose actions and utterances tell a lot about their people and societies. They are also eyewitnesses and reporters who communicate the painful stories of the pesons whom they converse with. Adnan reminiscences of the first man he met on the ninth of April, the day when the American forces entered Baghdad. This man who was "ill-dressed, poor looking, waving a photo of Saddam" was running in the middle of the street cursing Saddam and saying:

Saddam, you dog, you destroy my life! You sent me to fight the Iranians and see what they did to me! (He holds up his shirt to show a wound.)For what? For you? Now I'm old, my life is finished. I spit on you, I step on your face! May the Americans catch you and cut you into a thousand pieces! May they destroy your sons and their sons forever! (He puts the photo on the ground and stamps on it over and over until the light goes out) (p.12).

The circumstances that make Laith work as 'terp' with the American was quite incidental. He was standing with other Iraqis seeking a job or the help of Americans at an entry check point into the Green Zone. There was an old man who was clutching a sheet of paper and wanted to speak to Ambassador Paul Bremer(1961-), the leader of the occupational authority following the 2003 invasion of Iraq. The old man could not communicate with the American soldier as he could not speak English. There was also a woman in a black abaya (a traditional black long mantlewomen wear in Iraq) who also wanted to speak to the Ambassador. At this moment, Laith intervened to work as linguistic mediator. He translated what the old man was saying: "He wants to find out what happened to his four sons. They disappeared during Saddam's time. Their names are on this paper"(p.15). Unlike the old man, the woman "wants electricity, water, a job for her son, and she wants the American soldiers to arrest the criminal gangs in her neighborhoods"(p.16).

These two incidents shed light on the nature of the political system that reigned supreme in pre-2003 Iraq. They respectively refer to the catastrophic Iran-Iraq war which Workman(1994,p.1) aptly called "the third world's first great war," for, "its economic costs , physical destruction , and human toll", and to the killing, imprisonment, and forced disappearance of thousands of Iraqis during the Saddam reign which lasted for about thirty five years (1968-2003).

During this long period, the Iraqis were writhing under various forms of pressures and stifling circumstances ranging from tyrannical authority, a series of political and social unrests, prolonged and successive wars, and economic sanctions to absence of freedom of speech and living in a continuous state of fear and misery. Sadly enough, the Iraqis in those times, Al-Athari (2008,p.vii) points out, "could only watch as their country was, and still is, being torn apart by the havoc of war, insurgency, and sectarian violence" which erupted in the wake of the second Gulf war and post-2003 Iraq. The Iraqis, as a matter of fact, were living in those times in the "Republic of Fear," as the Iraqi exile Kan'an Makiya, who was then writing under the pseudonym Samir Al-Khalil describes it (for more information see Al-Khalil 1989).

These gruesome and shocking circumstances under which the Iraqis were living might explain the initial positive attitudes towards the arrival of American forces. Laith clearly remembers the first few months after the American occupation of Iraq when "everyone was so happy"(p.12, italics mine). 
Adnan was totally against the word 'invasion'. He used to defend the American and staunchly held the view that America was in Iraq to make a change (p.10). With the entrance of the American forces, it seems that all of Adnan's dreams have come true. Before 2003, there was a sound, as he describes it, at the back of his head that tells him:

the time will come, the time will come, the change will come. My time will come. It is not my destiny to live and die in Iraq like this. And when 2003 came, I couldn't believe how right I was.(p.10)

Adnan felt that he was wasting his life in Iraq before 2003. He experienced a new feeling when the war took place: he felt that he "will start to live"(p.27). However, rather than liberation as some Iraqis proclaimed, Adnan saw the American occupation as a chance not only for him, but for every Iraqi. His experience is the experience of all the Iraqis of his generation who "looked into the future and saw nothing, only darkness. We were living in this great prison"(p.26) called Iraq where fear, oppression and feelings of non-belonging dominate. For the first time, after 2003, the Iraqis can speak freely about Saddam, can freely express their opinions. They have more freedom, newspapers, satellites channels, ability to travel and they enjoy a better economic situation after the general rise in the wages and salaries.

Unfortunately, the arrival of the American forces has yielded not only good outcomes, but also bad ones. One of the most pernicious outcomes is the consolidation of religious extremism in Iraq which was divided among religiously diehard groups. Those groups impose their own narrow-minded and reactionary views on the people who live in the regions under their control. Adnan sheds light on the changes that took place in his neighborhood after al-Qaeda group became very strong. He describes the strict rules impose by al-Qaeda in detail. He says

No jeans, no shorts, no ladies driving. They threaten you if you have a spare tire in your car because this means that you do not trust in God's help. They killed a man who always sold ice next to the vegetable market...because they said there was no ice in the time of the Prophet. This is their religion.(p.62)

Besides religious extremism, Iraqis were struggling against another serious problem in their life: the destruction of the infrastructure especially the electricity power projects and the spread of corruption that threatens to demolish all hopes of rebuilding Iraq and bettering the life of its people. Al-Sadr city where Laith lives is a clear example of the failure of both the Americans and the post-2003 successive governments of Iraq to make the promised dreams come true. He tells Bill Prescott:

Bill, people in Sadr City were looking for any tangible project. At the embassy I hear numbers of budget, amounts of money, this sewer system is going to be repaired, such and such schools are being rebuilt. But in the streets in my area there is not a tangible project.(p.63)

Another chronic problem which the Iraqis are still suffering from is the struggle for power and the obnoxious political rivalry among the various power actors in Iraq. Each one of those actors is trying to make the utmost use of the situation to serve its own purposes. They are mainly responsible for the aggravation of most of the long-lasting ordeals Iraq is writhing under. Adnan makes this clear when he says "Political parties were encouraging the hate and telling the people this is your only chance now to survive"(p.73).

Both Adnan and Laith strongly believe in the importance and vitality of their work as translators. Adnan tells Prescott, the American Service Officer, that in order to succeed in Iraq after their quick military victory, they have to change to understand Iraqi society and culture. According to him, they, i.e., the Americans and Iraqis cannot "have life without a common language between [them]"(p.18). This common language is provided by the hundreds of translators and interpreters who work with the American and other Coalition forces. Apart from working as a translator to financially better his life, Adnan determinedly explains that his main purpose was to serve his country, Iraq (p.29). He wants to inform the American of what exactly is going on, to help them better understand the current political, social and cultural situation in his country. He does not consider the American his enemies. Rather, he was a life-long admirer of American culture and people. He used to listen to American songs and watch a lot of American movies on television. He loved leaning English language because, he thought, it "opens horizons" for him(p.10). Because of the heavy censorship on Arabic books, he 
preferred to read English books which mostly deal with philosophy and adventure. Working as a translator offered Adnan a golden chance to be in direct contact with the people and culture he long admired.

In their work with the American, Laith and Adnan engage in carrying out a number of jobs like translating the documents, interpreting during interrogations, going with the American forces on raids, and also informing them of the cultural and social habits concerning the role religion plays in the life of Iraqis, customs of marriage, position of woman, and man-woman relationship. The challenges the translators experience are not related to these activities. Rather they are related to the ambivalent nature of their existence between two societies, languages and cultures. Failure to understand the nature of the translators' work and its implications for their life and safety on both sides of the conflict results in putting their lives in a great danger. A short encounter between Laith and Dishdasha (kind of a long gown for men) Man who came to the Green Zone to ask about his brother who was arrested by the American is an example of the dangers the translators are daily experiencing. After trying to soothe the angry Dishdasha Man and translating his conversation with the American soldier, the Man looks at Laith intently, points his finger threateningly and says hatefully something that makes Laith shake in fear. He nervously says "Why do you work as an agent of the occupier? There is no safe place for traitors in Iraq"(p.22).

This is the main problem suffered by most translators in Iraq. In spite of the decisive role they play in the conflict zones, their work is not appreciated. They are leading a continuously precarious life in which they are considered transtraitors. Laith believes that American should do something to change this stereotypical picture. He accuses the Baathists of distorting the image of those who are working with the Americans, whether politicians, contactors, translators or civilians. He says:

The Baathists are making people believe that Iraqis like me are traitors; we are giving up Iraqis with false information and women are getting raped. American must put their message on television in a way that Iraqis can understand. Iraqi people listen to the Baathists in their neighborhoods, they hear al-jazeera and Iranian television, and so they think you are stealing the resources. They hear nothing from American, they get nothing from Americans. This is very dangerous for you and me. (p.22)

In fact, Laith and Adnan are not only alienated from their countrymen, they also suffer gradual alienation and hostility from the Americans themselves. After the initial spout of enthusiasm and readiness to work with the Americans in the hope that this might help their country, both begin to have their doubts in the Americans' seriousness and desire to grant them the same degree of protection and interest as the Aericans. Laith asks the soldier to turn off the spotlight on top of the Assassin's Gate because when he walks home, his shadow shows from a very far distance(p.23). When Laith met one of the snipers who is supposed to protect him, as the soldier promises, and thanks him, he was shocked upon discovering the truth. He says "I was naïve, I believed the Americans wouldn't lie to us. We were friends, yeah, but they didn't trust us. That was my first shock-nobody's looking out for you. You're on your own"(p.24).

Another incident which reveals how vulnerable the life of the translators in Iraq was occurred when the American Regional Security Officer (RSO) insistently refuses to upgrade the entry badges and change them from yellow to green just like the Americans who are working in the Green Zone. The RSO believes that because Adnan and Laith are living in the Red Zone, i.e., Iraq, granting them the green badge might pose a threat to the American embassy and its staff. According to him, they might be forced by insurgents to smuggle weapons and other dangerous materials. In spite of the Ambassador's admission that the translators are the 'ears' and the 'eyes' of the embassy and that the Americans can do nothing without their help, he does nothing to help them and let them wait "in line for hours with all the other Iraqis...open to threats, to car bombs, to the sun, to the rain"(p.55). Laith also reports that the Americans never gave him good body armor when he went with them on raids and they took him out on patrol in his own neighborhood although he told them that it was very dangerous(p.35). Consequently, both Adnan and Laith have to remain invisible all the time: to keep their real work secret, to change their names, to use bandannas over their faces, to use many cellphones and to keep changing their dwelling places. 
The status of the female translators who are working with the Americans is more critical and alarming than their male colleagues. Intisar, the third translator/character in Betrayed is a case in point because working with the American means not only betraying her people and collaborating with the enemy, but also defying the norms of her predominantly conservative and patriarchal society. Without question, the attitudes toward Intisar are gender-based. She is criticized, severely reproached and ultimately killed by a military militia not only because she is a translator, but also because she is a woman. Before the coming of Americans, Intisar's dreams were very simple. As a young girl, she dreams of riding a bicycle like her brothers in the streets of Baghdad without being looked at as a 'crazy person'(p.32). She explains that she was forced to do many things she hates during Saddam's era. She no longer wants to do "anything that someone obliges [her] to do"(p.33). One of these things is wearing hijab or head cover which she decisively refuses. Because of her refusal, people in her neighborhood often look at her with hate. One of them harshly and menacingly said to her "This is our area and our rules must be followed"(p.33). She also has to wear more conservative clothes than before, to hide her makeup and perfume in her desk and to wash them off before she goes home. As Intisar painfully explains "the general idea that other people have about women who work in the Green zone is ....she's a bitch. She's there to entertain the Americans"(p.41). Another man called Eggplant Face reiterates the same idea when he questions Intisar about her work and the reason behind her not wearing hijab. He says "there are rules here. The defenders of this area will not allow a woman to look like a prostitute"(p.49). She also hears men at the checkpoints while she is waiting to enter say nasty things about her.

In fact, the painful experiences Intisar has in her work and personal life is not exceptional. In her seminal study, "Reconstructing Gender: Iraqi Women between dictatorship, war, sanction, and occupation," Al-Ali (2005) presents a historical survey of that impact of the three decades of authoritative rule, successive wars, economic sanctions, and gradual Islamisation of society on the status of Iraqi women. Al-Ali believes that it is against this bleak political and economic background that the status of Iraqi women should be analysed and understood. As a result of the deterioration of security, militarization of society and dominance of masculine and patriarchal values, women often suffer a severe backlash in war situation especially when "traditional gender roles inside the home or outside are evoked"(p.742). This may explain the high level of violence practiced against women which takes many forms like violation of human rights, deprivation of education, imposition of certain dress codes, early marriages, harassment and even abduction and rape (for more information, see Al-Ali).

Thus whether male or female, the Iraqi translators, just like their other fellow citizens were facing the same ordeals and problems. However, due to their existence in an inbetween space between their countrymen and the Americans, they were doubly alienated and estranged. In order to survive, they have to resort to a number of techniques and tricks.

\section{CONCLUSION}

It is crystal clear that the picture given by the three translators, Laith, Adnan, and Intisar about the pre-and post-2003 Iraqi society is far from being promising or optimistic. In fact, the translators' accounts of life in post-2003 Iraq dribble with images of pain, suffering, and fear. Like the other Iraqis, the translators have a first-hand experience of different sorts of violence and abuse such as killing, kidnapping, running a fugitive life, losing job as well as identity and living under threat all the time. Although Betrayed was written about eight years ago, the horrific events reported by its main characters tell that little has changed in Iraq for the car bombs, militias, explosions, crimes, death, political rivalry, ethnic and religious divisions, violence and destruction continue till now. Iraqis, among them the translators have not known yet the real pleasures of peace, safety, and happiness which other peoples have.

Unlike the previous studies which focus on the occupational hazards and deathtraps faced by the translators in the conflict zones, this paper focuses on the untold and small stories, to use Bamberg's term (for more information see Bamberg and Georgakopoulou, 2008), that go beyond the acts of translation. These stories come "from the horse's mouth" as Laith says (p.9). Although they revolve around the problems the translators suffer in their work, these stories end up talking about the problems of all Iraqis. 


\section{REFERENCES}

Adelman,H. (2008). The refugee and the IDP problem in Iraq. In H. Adelman (Ed), Protracted displacement in Asia: No place to call home(181-209). Hampshire: Ashgate Publishing Limited.

Akbari, M. (2013). The role of culture in Translation. Journal of Academic and Applied Studies 3(8) August 2013, pp. 13-2.

Al-Ali, N. (2005). Reconstruction Gender: Iraqi women between dictatorship, war, sanctions and occupation. Third World Quarterly, 26(4-5), 739-758.

Al-khalil, S. (1989). Republic of fear: The politics of modern Iraq. Berkeley: California UP.

Al-Athari, L. (2008). This rhythm does not please me: Women protest war in Dunya Mikhail's poetry. Kansas: Kansas State University.

Baigorri-Jalon, J. (2010). Wars, languages and the role(s) of interpreters. Beyrouth, Lebanon. Retrieved April,15,2015, URL(HALhttps://hal-confremo.archives-ouvertes.fr/hal-00599599), $173-204$.

Baker, M. (2010). Interpreters and Translators in the War Zone: Narrated and Narrators, The Translator 16(2), 197-222.

Bamberg, M \& A. Georgakopoulou. (2008). Small stories as a new perspective in narrative and identity analysis. Text \& Talk 28(3), 377-396 (DOI 10.1515/TEXT.2008.018).

Chou, M.(2009). From page to stage: What emerges 'In between' politics and art in George Packer's Betrayed. Borderlands, 8(3). Retrieved November 12, 2015. URL(www.borderlands.net.au)

Inghilleri, M. \& S. Harding. (2010). Translating the conflict. In M. Inghilleri \& Sue-Ann Harding (Eds). The translator: Studies in intercultural communication, 16(2), London: Routledge, 165175.

Juvinall, B. (2013). Heaven or hell? The plight of former wartime interpreters of the Iraq and Afghanistan conflicts living in the US. Michigan State International Law Review 21(1), 204-226.

Omar, O. (2008). The Translators of the American Forces: Tight Control. Retrieved March, 1, 2016. URL (http://www.niqash.org/articles/?id=2303\&lang=ar)

Packer, G. (2008). Betrayed. New York: Faber and Faber, Inc.

Packer, G. (2007). "Betrayed-The Iraqis who Trusted America the Most." Retrieved March,1, 2016. URL(http//www.newyorker.com/magazine/2007/03/26/betrayed-2)

Palmer, J. (2007). Interpreting and translation for western media in Iraq. In M. Salama-Carr (ed.) Translating and Interpreting Conflict(13-28), Amsterdam \& New York: Rodopi.

Peter, T. A. (2008). An Iraqi interpreter as chronicler of the war. The Christian Science Monitor. Retrieved February, 28, 2016. URL (www.csmonitor.com/)

Rafael, V. L. (2009). Translation, American English and the national insecurities of empire. Social Text 101, 27(4), Duke UP.: 1-23 (DOI 10.1215/01642472-2009-052)

Workman, W. T. (1994). The social origins of the Iran-Iraq war. Boulder: Lynne Rienner.

Zagolin, J. (2015). Survival of the warzone interpreter: Behind the untold story. Bolongna University. Retrieved February, 28, 2016. URL (amslaurea.unibo.it/9164/4/zagolin_jessica_tesi.pdf)

\section{AUTHOR's BIOGRAPHY}

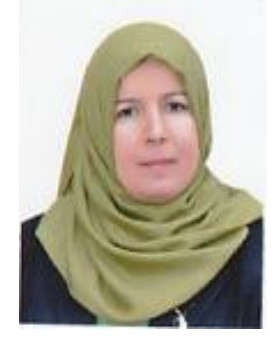

Prof. Hana Khlaif Ghena, Ph.D in English literature from Baghdad University, College of Arts, Department of English (2005). Major Fields of study include English Literature, Modern British and American Drama, Greek Tragedy and comparative studies.

She is working a teaching staff in University of Al-Mustansiriya, College of Arts, Department of Translation (2004). She published more twenty three papers inside and outside Iraq. She also translated ten books into Arabic. 